\title{
Bio-Organic Mineral Fertilizer for Sustainable Agriculture: Current Trends and Future Perspectives
}

\author{
Shameer Syed ${ }^{1,2,+}$, Xingxing Wang ${ }^{1,+}$, Tollamadugu N.V.K.V. Prasad ${ }^{2}$ and Bin Lian $1, *$ (D) \\ 1 College of Life Sciences, Nanjing Normal University, Nanjing 210023, China; syeds962@gmail.com (S.S.); \\ wangxxnnu@163.com (X.W.) \\ 2 Nanotechnology Laboratory, Institute of Frontier Technology, Regional Agricultural Research Station, \\ AN-GRAU, Tirupati 517502, India; tnvkvprasad@gmail.com \\ * Correspondence: bin2368@vip.163.com; Tel.: +86-189-5180-6649 \\ + These authors contributed equally to this work.
}

check for

updates

Citation: Syed, S.; Wang, X.; Prasad, T.N.V.K.V.; Lian, B.

Bio-Organic Mineral Fertilizer for Sustainable Agriculture: Current Trends and Future Perspectives. Minerals 2021, 11, 1336. https://doi.org/10.3390/ $\min 11121336$

Academic Editors:

Mostafa Benzaazoua and

Carla Patinha

Received: 21 October 2021

Accepted: 26 November 2021

Published: 29 November 2021

Publisher's Note: MDPI stays neutral with regard to jurisdictional claims in published maps and institutional affiliations.

Copyright: (c) 2021 by the authors. Licensee MDPI, Basel, Switzerland. This article is an open access article distributed under the terms and conditions of the Creative Commons Attribution (CC BY) license (https:/ / creativecommons.org/licenses/by/ $4.0 /)$.

\begin{abstract}
Chemical (synthetic) fertilizers used indiscriminately for improved production pose a major threat to long-term soil fertility, the soil environment, and its components. The soil microbial community, however, plays a major and important role in fostering soil health and plant growth. While the use of synthetic fertilizers has a profound impact on plant growth, it also significantly alters the makeup of the microbial community towards a detrimental low, especially $\mathrm{N}$ and $\mathrm{P}$ fertilizers. Sustainable farming practices can reduce the depletion of natural resources and maintain both productivity and soil fertility. The use of minerals that contain fertilizer nutrients in their native state is a very promising approach to reducing emissions associated with the processing chemical industries. Organic material from natural sources (food waste, manure from livestock, agricultural biomass, etc.) acts as a source of microbial culture and encourages the release of nutrients into the soil during mineral weathering. The combination of nutrient-bearing minerals and their biological weathering agents together with organic matter has the potential to remediate, restore, and sustain depleted agricultural soils. Therefore, in this review, we emphasize the significance of sustaining agricultural productivity and microbial diversity in the rhizosphere, the two vital aspects of modern agricultural systems, through bio-organic mineral fertilizers.
\end{abstract}

Keywords: organic fertilizers; mineral fertilizer; soil microbes; sustainable agriculture; pollution

\section{Introduction}

In the long-term biological-geological co-evolution, the life activities of surface microorganisms play an important role in a series of surface geochemical processes, such as rock weathering, soil formation and evolution, which directly or indirectly affect the growth of various soil organisms, including the massive formation of terrestrial vegetation. It can be said that the growth of surface plants depends to a large extent on the mineral nutrients released by soil microbial-mineral interactions. With population growth and human science and technology progress, the yield of crops increased significantly. The nutrients provided by the weathering of rocks under natural conditions was no longer able to meet the needs of the normal growth of plants, prompting the discovery and utilization of chemical fertilizers in the 18th century, and their rapid development as an important guarantee for improving crop yield and quality. Intense agricultural practices, especially the indiscriminate utilization of synthetic compounds $(\mathrm{N}, \mathrm{P}$, and $\mathrm{K})$ has been increasing steadily in most parts of the world. Intense agricultural practices combined with approaches such as the reclamation of degraded soils to enhance food productivity, have created repercussions beyond human control/comprehension. The degradation of fertile soils, attributable to intense agricultural practices, is a major hurdle for food security and sustainable agricultural development. As degraded soils feature relatively lower levels of essential soil nutrients, active organic carbon, low or high $\mathrm{pH}$ coupled with 
limited soil enzyme activity usually generate low yields and nutritionally subpar produce. Furthermore, excess chemical fertilizers impact the rhizosphere's microbial communities adversely, disrupting their normal soil functions (nutrient cycling, organic matter creation, soil nutrient improvement). However, due to rapid developments in industry, agriculture, and population growth, large areas of fertile soils were either degraded or converted into non-agricultural activities [1], and many areas of newly reclaimed soil (most of which are poor soils), have been adapted for plant cultivation. Many reclaimed soils, along with degraded soils, are characterized by sufficient contents of nutrients $(\mathrm{K}, \mathrm{Ca}$, and $\mathrm{Mg})$ but remain in indiscerptible chemical states, are not absorbed by the plants, and often present as soil minerals. In addition, the long-term use of chemical fertilizer leads to the increasingly evident problem of heavy metal pollution in cultivated soil.

Despite the innovations and modern approaches in recent agricultural practices, the majority of the global agriculture sector still depends on conventional practices; thus, it suffers from sustainability and fertility issues. Moreover, soil fertility continues to decline due to the increase of multiple cropping practices and increasing agricultural yields through the misuse of chemical fertilizers [2]. Hence, measures to improve these soils are urgently required, as global agriculture is being significantly hampered by various yield-limiting factors (increased disease occurrences, pest and insect invasions, erratic weather). Furthermore, agricultural activities are controversially deemed a major $\mathrm{CO}_{2}$ contributor to damage to the atmosphere, driving global warming.

Excessive use of chemical fertilizers not only increases production costs, but also causes problems such as energy depletion, resource scarcity, and environmental pollution as well as compromising food safety, which have become increasingly prominent challenges in recent years. Against the current background of the vigorous development of ecological agriculture and environmental protection, the role of organic matter returning to the field and the development of organic fertilizers on this basis has received renewed attention in agricultural production. Adding organic matter to cultivated soil increases the soil's organic content, regulates the soil's physical and chemical properties, and improves the quality of agricultural products, but a large amount of organic matter in cultivated soil inevitably increases cultivated soil respiration. Facing the global greenhouse effect, the negative impact of organic matter returning to farmland should not be ignored.

Minerals are also an important component of the soil; they are the skeleton of the soil and the source of mineral elements. Minerals play an important role in the improvement of soil's physical and chemical properties and the growth and metabolism of microorganisms. However, the beneficial effects of the use of appropriate minerals in the soil have long been neglected. In addition, our research has found that forms of mineral weathering, such as silicate weathering, are often accompanied by the formation of secondary carbonate minerals in the process of biological weathering, which undoubtedly increases the potential of cultivated soil carbon sinks [3-6]. Further studies have shown that secondary minerals formed with mineral weathering have a good remediation effect on heavy metal pollution $[7,8]$. In addition to the formation of secondary minerals, the cations released by mineral weathering can also combine with the soil's organic complexes through co-precipitation, which in turn mediates the formation of soil aggregates, preserving soil organic carbon, thereby reducing the potential of soil carbon depletion. Therefore, bio-organic mineral fertilizers (BOMFs) have a positive impact on agriculture, soil health and the ecological environment [9-14]. In this review, we emphasize the application urgency, production methods and ecological effects of BOMFs, and point out the future research direction of BOMFs, hoping to provide a new vision for the development of sustainable agriculture.

\section{BOMFs: A Current Need}

By the end of 2020, the total global amount of fertilizer (N, P and K) reached more than 200 million tons per year [15]. This is alarming as fertilizers have severe adverse effects on soils as well as on surrounding ecosystems. In addition to this, the use of pesticides to prevent and control plant diseases is accelerating at a much more perilous rate. 
China $(1,773,676 \mathrm{t})$, the United states of America $(407,779 \mathrm{t})$, and Brazil $(377,176 \mathrm{t})$ occupy the top three places in the world for pesticide utilization as of 2019, according to FAO. However, concerning the consumption rate ( $\mathrm{kg} /$ hectare), Maldives (52.6), Trinidad and Tobago (24.9) and Costa Rica (22.5) are the top three consumers of pesticides despite their smaller areas of agriculture [16]. Long-term conventional farming has far reaching consequences for human health and the environment [2,17-19].

As a response to the many hurdles, contemporary and very recent research has demonstrated that soil quality can be improved by applying organic matter, organic fertilizer (OF), dust, and mineral powder (MP), and/or by growing pasture legumes as green manure [20-22]. The natural breakdown of many minerals due to microbial metabolic activities, combined with abiotic factors innate to a given ecosystem, provide sustenance to plant growth $[7,23]$. It is a widely acknowledged fact that organic matter is a crucial component for improving the physical properties of soil, and that returning organic matter to soil can increase the content of soils' active organic carbon (AOC) and improve soil vitality. However, organic matter alone, which lacks adequate accessible nutrients (for plants), exerts slow and variable effects on crop growth [24]. Although applying chemical fertilizers ( $\mathrm{CFs}$ ) can promote rapid crop growth, extensive $\mathrm{CF}$ use has reduced soil quality worldwide [25]. Utilizing and/or enhancing the mineral weathering potential of many microbial groups (bacteria and fungi) coupled with mineral ore (rock phosphate, feldspar, etc.) application has been reported to exert extremely positive effects on soil health and fertility, an approach devoid of environmental concerns $[13,23,26,27]$. Hence, compound fertilizers composed of suitable microbes, organic matter, and raw mineral powders, along with low quantities of $\mathrm{CF}$, offer the potential to achieve sustainability goals under the prevailing environmental scenario $[10,28,29]$.

Contemporary research shows that potassium-containing minerals transformed by microorganisms in soil can promote crop growth [30-33]. For example, Paenibacillus mucilaginosus (also known as silicate bacterial in China) is an important species, widely used in microbial fertilizers in China [33-36]. Lian et al. (2002 and 2020) explored the potassium-releasing effect and mechanism of bacteria, and proposed the comprehensive effect of the potassium-releasing mechanism by bacteria. The potassium release effect of silicate bacteria on aluminosilicate-containing potassium minerals is based on the formation of a bacteria-mineral complex through the combined effects of acidolysis, chelation, dissolution, and active absorption, which promote each other and together lead to the gradual release of potassium ions in minerals. Further, the micro-environment formed by microbial extracellular secretions and microbial-mineral interactions (bacteria-mineral complex) is closely related to the release of potassium ions from mineral weathering [9-11]. These findings helped to further the understanding of the mechanism of weathering potassium-bearing minerals to improve soil potassium utilization rates through silicate bacteria.

In some areas, Chinese farmers have used potassium-containing mineral powder, phosphate rock powder, agricultural by-products, and organic wastes to make compost $[5,37,38]$. This method of fertilizing fields by supplementing potassium and phosphorus is simple but varies greatly in its effect on crops. In recent years, some scholars have also begun to try similar methods to obtain organic potassium phosphate fertilizers using different organic materials and minerals, supplemented with microbial agents $[8,14,39-41]$. The results indicate that fermentation with a microbial agent greatly increase the soluble content of nutrients $(\mathrm{K}$ and $\mathrm{P})$, suggesting that microbial fermentation can efficiently transform low-grade mineral rocks. Furthermore, potassium-containing rocks and auxiliary materials can be converted into multifunctional compound organic mineral fertilizers, which can not only supplement the nutrients needed for crop growth and improve its quality, but also repair inferior soil that has been severely degraded due to the excessive application of chemical fertilizers $[5,13,28]$.

In summary, BOMFs are fertilizers prepared with minimally processed components (chemical agents such as urea, phosphates, etc.). BOMFs mostly comprise mineral sources and animal excreta (cow dung, chicken feces, etc.) as bio-organic components and differ 
significantly from conventional organic fertilizers or bio-fertilizers in their composition and resultant effects. The components and basic differences with conventional chemical fertilizers are presented in Table 1.

Table 1. Differences in compositional and functional attributes between BOMFs and conventional synthetic fertilizers.

\begin{tabular}{lcc}
\hline Different Distinguishing Components & BOMFs & Conventional Fertilizer \\
\hline Mineral source (P, K, Ca, B, Mg, etc.) & Natural & Chemical \\
\hline Mineral (dust or powder) & $\checkmark$ & x \\
\hline Microbial agents & $\checkmark$ & x \\
\hline Plant growth-promoting microbes & $\checkmark$ & x \\
\hline Plant protecting microbes & $\checkmark$ & x \\
\hline Organic carbon & Natural (animal waste) & Chemical (urea) \\
\hline Nitrogen source & xx & Chemical additives \\
\hline Inorganic additives & (P, K, etc.) \\
\hline Negative impact environment & $\checkmark$ & $\checkmark$ \\
\hline Known CO 2 sequestration potential & $\checkmark$ & x \\
\hline Positively influences soil parameters & x & x \\
\hline
\end{tabular}

Note: $\checkmark$ means contained, $x$ means excluded, $x x$ means excluded unless otherwise noted (adding a small amount of chemical fertilizer).

Additionally, the organic component serves two functions: as a carrier for the microflora and as an active soil carbon source, further improving soil fertility. The most noticeable feature of BOMFs is the presence of a natural, unprocessed mineral source instead of chemical agents for supplementing macro-elements (phosphate, potassium, calcium, magnesium, sulfur, boron, etc.). Phosphate (P), the most widely applied nonnitrogen fertilizer, features limited bioavailability in its raw form (rock phosphate or phosphorite), needing further chemical processing before its application to soil. This can be managed with BOMFs, where rock phosphate itself is used as $\mathrm{P}$ source that is gradually weathered by the action of innate/or added microflora in BOMFs. Besides P, many other macro-elements can be supplemented as their raw sources (feldspar, muscovite-potassium; dolomite-magnesium; calcite-calcium; gypsum-sulfur) before high-temperature fermentation. Furthermore, BOMFs can be prepared with widely available materials, reducing the manufacturing process as well as the financial pressure on the farmer to obtain healthy produce from the fields. BOMFs could also be much more effective in soils lacking pedogenic parent minerals (such as karst soils in Southwest China, sodic soils in south Asian countries, and sandy soils in Africa) as the mineral component can be gradually weathered by microbial community-enhancing soil agricultural attributes. Thus, the organic mineral fertilizer obtained by comprehensively using organic waste and cheap low-grade mineral powders (such as potash mineral powder and phosphate rock powder, etc.) and adopting microbial engineering fermentation technology can partially replace chemical fertilizers to promote crop growth, improve low-quality soil, and exert a positive ecological effect (Figure 1). 


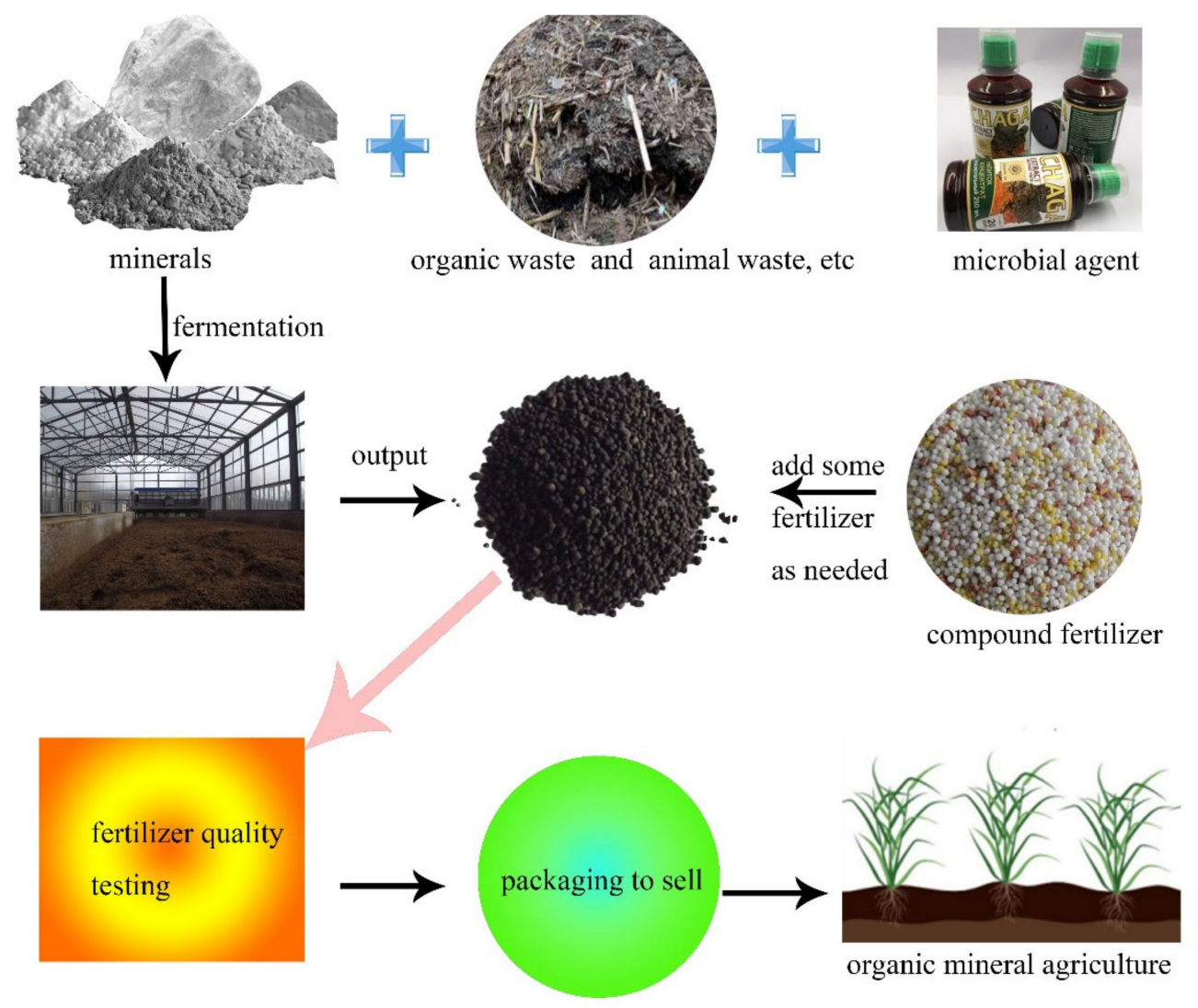

Figure 1. Simplified production process of BOMFs.

\section{Sources, Production Methods and Comparison of Usage Costs}

The preparation of BOMFs is less complex and chiefly involves simple biological and physical methods (Figure 1). The components or the general make-up can vary greatly depending upon the soil type, location (e.g., tropical, sub-tropical, or temperate), physicochemical traits and deficiencies, etc. For example, the organic component can be dependent on the most abundantly or conveniently available source, such as agricultural waste, animal manure and/or compost $[3,13,28]$. Animal manure (chicken excreta or cattle dung) or vermicompost can be used with little processing, and without the need for high-end processes. Furthermore, the mineral component is generally a mineral ore (commonly low-grade) composed of different macronutrient elements. Minerals such as phosphorite, feldspar, gypsum, basalt, etc., containing macronutrients (such as $\mathrm{P}, \mathrm{K}, \mathrm{Ca}, \mathrm{Mg}, \mathrm{S}, \mathrm{B}$ ), are common mineral additives. Thus, the compositional make-up of the components and the produced BOMF can greatly vary. The bio-organics' and minerals' basic composition is provided in Table 2.

BOMFs significantly increase the organic content in soils as they provide a stabilizing balance between mineral, biological, and organic components. The microbial community innate to the organic material weathers the powdered ore slowly but steadily, creating a stable source of nutrients and improving the soil parameters, especially if active bacterial agents are applied as additives.

According to the typical fertilization situation, the amount of chemical fertilizer used is about $4.5 \mathrm{t} / \mathrm{hm}^{2}$, and the input cost is $4800-6000 \mathrm{RMB}$. Although the organic content of organic fertilizer is higher, the pure nutrient content is much lower than that of chemical fertilizer. The use amount of organic fertilizer converted according to the nutrient content of chemical fertilizer is about $22.5 \mathrm{t} / \mathrm{hm}^{2}$. Taking into account the transportation cost and labor cost, the cost of using organic fertilizer needs to be increased by about 2500 RMB [46], Therefore, the use of commercial organic fertilizers needs to be subsidized by the government, otherwise it will be difficult to use on a large scale. Compared with 
the former two, the usage cost of BOMFs is close to that of high-grade organic fertilizer. Since the use of mineral powder and organic matter is mainly based on the principle of using local resources (mineral and organic resources), the cost of using BOMFs will include a significant amount of room for reduction. The following mainly explains the advantages of using BOMFs from the perspective of improving soil's physical and chemical properties and increasing soil carbon sinks.

Table 2. Basic compositional make-up of different components employed in the production of BOMFs.

\begin{tabular}{|c|c|c|c|}
\hline & Ingredient/Component & Major Nutrients & Nutrient Availability \\
\hline \multicolumn{4}{|c|}{ Mineral } \\
\hline i. & Phosphorite or rock phosphate & Phosphorous $\left(\mathrm{P}_{2} \mathrm{O}_{5}\right) 16-17 \%$ & Slow \\
\hline ii. & Feldspar & Potassium $\left(\mathrm{K}_{2} \mathrm{O}\right) 2-12 \%$ & Very slow \\
\hline iii. & Gypsum $^{\text {a }}$ & Sulphur $\left(\mathrm{CaSO}_{4} 12-16 \%\right)$ & Slow \\
\hline iv. & Basalt $^{b}$ & Iron (FeO 5-14\%) and magnesium (MgO 5-12\%) & Slow \\
\hline $\mathrm{v}$. & Calcite or dolomite & Calcium ( $\mathrm{CaO} \sim 12 \%$ ) Magnesium ( $\mathrm{MgO} \sim 20 \%$ ) & Very slow \\
\hline \multicolumn{4}{|c|}{ Bio-organics } \\
\hline i. & $\begin{array}{l}\text { Animal manure }{ }^{c} \text { (cattle dung and } \\
\text { poultry excreta) }\end{array}$ & $\begin{array}{c}\text { Nitrogen }(\sim 14 \%) \text {, potassium }(\sim 20 \%) \text {, and } \\
\text { Phosphorous }(\sim 25 \%)\end{array}$ & Quick \\
\hline & Compost $^{\mathrm{d}}$ & Potassium, nitrogen, and phosphorous & Quick \\
\hline
\end{tabular}

\section{Ecological Effects of BOMFs}

The application of BOMFs in agriculture can improve soil's physical and chemical properties, regulate soil ecological communities, and reduce environmental pollution. Beneficial rhizosphere bacteria play a critical role in the agricultural ecosystem i.e., by preserving soil quality and maintaining soil fertility and crop productivity [47]. An appropriate community structure, rich diversity, and high microbial activity are significant factors in maintaining soil ecosystems and productivity [48].

\subsection{Impacted Microbial Functions and Plant Growth Promotion}

Years of different types of fertilizer application (including NPK, manure, and cattle slurry) demonstrated statistically significant differences in the content and quality of humic substances, soil reaction and available nutrient content. Based on principal component analysis, fertilizers are divided into two categories: (1) NPK treatment-higher acidity, lower soil organic carbon and humic substances content, higher content of available nutrients; and (2) organic manure treatments-lower acidity, higher soil organic carbon and humic substances content, lower content of available nutrients. Organic manures are known to improve microbial community stability and enhance associated functions [49]. Furthermore, long-term NPK application without organic input can accelerate humus mineralization and soil degradation due to soil acidification, with several negative consequences, such as low nutrient availability, nitrogen leaching, high toxic element availability, fewer sources and energy for microorganisms' activity etc. [50-52]. Amendment through the use of organic 
fertilizers (manure and cattle slurry) and BOMFs can help to achieve stable yields in the long term while maintaining optimal soil properties. The total microbial diversity and density significantly increase along with the microbial community-associated functions (soil enzyme activity, organic carbon and total available nutrients such as N, P, and K) [53-56]. BOMFs also enhance the disease suppression potential of soils by maintaining stable rhizosphere microbial communities [57].

\subsection{Restoration of Soil Fertility and Organic Carbon}

The loss of fertility due to intense agricultural practices in the current scenario is of immense significance. Enhancing fertility in intense farms or in non-arable lands is a possible approach to increasing productivity, thus increasing food production without further burdening natural resources. The unique combination of BOMFs with the supplementation of natural organic matter, raw natural ores instead of synthetic fertilizers, and microbial assemblages capable of weathering, metabolizing and nourishing, could create a stable agricultural microenvironment. Sun et al. (2019) reported an increase in the soil water holding capacity and agronomic characteristics along with an increase in the biomass of Chinese cabbage when fertilized with BOMFs (in this case, potassic rock and organic waste) [5]. Additionally, the concentration of inorganic carbon (largely in the form of $\mathrm{HCO}_{3}{ }^{-}$) in surface run-off water treated by BOMFs was higher than in the other treatments, establishing carbon sequestration's potential. The combined addition of dolomite and K-feldspar mineral powder to soil has been shown to be effective at improving the plant growth parameters as well as carbon capturing. Plants and microorganisms weather minerals by secreting organic acids, which release cat ions, such as $\mathrm{Ca}^{2+}$ and $\mathrm{Mg}^{2+}$. The released cat ions manage atmospheric $\mathrm{CO}_{2}$ by forming carbonates under a series of biological actions [3-5,23]. In addition, the cat ions released by mineral weathering are often combined with organic matter, which is sequestered in secondary carbonate minerals when carbonate minerals are formed. These sequestered organic carbons are difficult to decompose and utilize for organisms, thereby increasing soil organic carbon. In one study, the carbon content of the soil was enhanced as mineral weathering accelerated fixation of organic and inorganic carbon. Moreover, the available potassium content was also increased when K-feldspar was added [4]. Facing the global greenhouse effect and cultivated soil degradation, adding moderate amounts of carbonate, phosphorus, and silicate minerals into soil is a sustainable approach through which to accelerate atmospheric $\mathrm{CO}_{2}$ fixation and improve the nutrient content of soil.

\subsection{Remediation of Degraded Soils: Cultivation of Specific (Resilient) Crops}

Soil fertility degradation is a serious and continuously increasing threat to agricultural soil productivity. Thanks to the use of BOMFs, resilient crops such as purslane have shown promising potential for reducing the negative effects of intense cultivation under the influence of chemical fertilizers, as observed in our research [13]. Yu et al. [39] and Xiao et al. [3] reported that the heavy use of chemical fertilizer causes increasing soil and environmental crises, and amendment through the use of organic components and biological agent increases soil health. The major functions, such as $\mathrm{pH}$, organic carbon content, microbial biomass, urease activity, and available potassium content were influenced when BOMFs were used. The cultivation of crops such as amaranth and purslane [13] exhibited the greater positive impact of BOMFs on soils and environments. In the case of both amaranth and purslane, the above-ground biomass and nutritional parameters of the plant were improved, suggesting the positive impact of BOMFs on agricultural soil as well as crops. It should be further noted that BOMFs are also affective in remediation of soil pollution, as reported by Chen et al. [40]. In pot experiments simulating karst mountainous area and heavy metal contamination (cadmium) using pakchoi cabbage (Brassica rapa chinensis), the results demonstrated that the heavy metal accumulation in BOMF-treated plants was the lowest, suggesting the effectiveness of mineral-microbial combinations. 
In summary, the application of BOMFs in farmland can improve the physical and chemical properties and structure of the soil $[58,59]$, regulate soil microbial community composition $[18,59]$, and promote the healthy and robust growth of crops by increasing the richness and uniformity of beneficial microbial communities [60] (Figure 2).

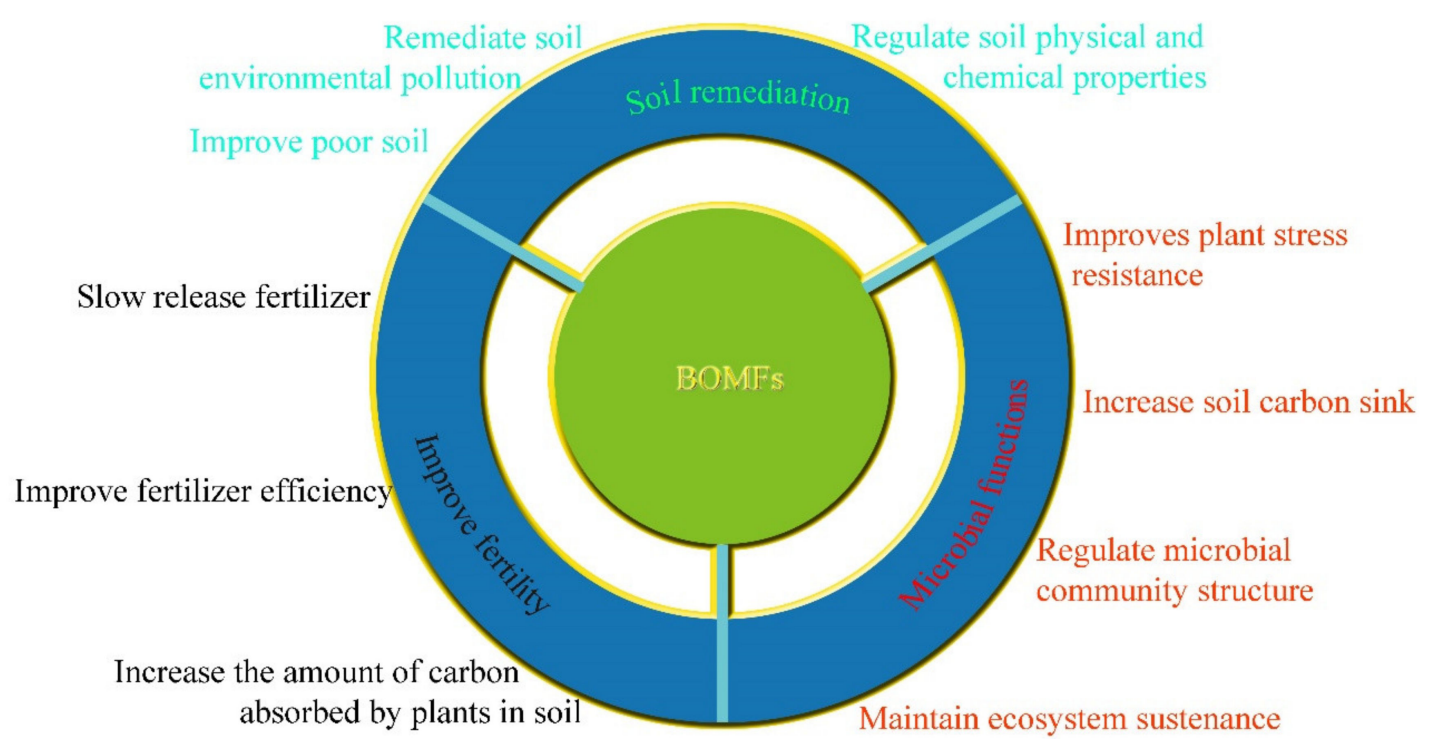

Figure 2. Ecological effect of BOMFs application.

In addition, the improvement of agricultural soil can improve the agricultural ecological environment, improve the quality of agricultural products, increase economic income, and promote the prosperity of people in rural areas so that they can live and work in peace and contentment.

\section{Conclusions and Prospects}

BOMFs play a crucial role in stabilizing the needs of intense agriculture and its impact on soil health and ecosystem functions driven by the resident microbial community. The amalgamation and application of organic matter and low-grade mineral sources of potassium, phosphorous, and other essential plant growth nutrients can rejuvenate depleted soil traits, such as organic carbon, total carbon, total nitrogen, and humic compounds, and improve the physical and chemical properties of soil. BOMFs and adaptive/resilient crops' combined cultivation can be highly effective in replenishing the agricultural strips downgraded by intense agricultural practices. BOMFs also enhance plant productivity as an outcome of multiple driving factors in long-term applications compared to synthetic fertilizers or traditional compost alone. Furthermore, the application of BOMFs can reduce the amount of chemical fertilizer, consequently reducing the environmental pollution caused by the production, processing, and consumption of chemical fertilizer.

BOMFs can only be used as slow-release fertilizers, and it is difficult to provide sufficient mineral nutrients for the growth of crops in a short period of time. Therefore, it is necessary to use BOMFs in combination with an appropriate amount of chemical fertilizer. Since BOMFs contain a certain amount of minerals, the mineral types should be mainly basalt, volcanic rock and clay rock, rich in mineral elements, and should be used on the principle of convenience in order to reduce production costs. It must be noted that some rock powders contain rich heavy metals, which are released during mineral weathering and cause environmental pollution. Therefore, the selection of minerals and the amounts in which they are added require sufficient field trials. In short, although the combined application of minerals and organic fertilizers has shown beneficial effects, further research is still required on soil heavy metal pollution, the optimum combination and processing of mineral and organic matter, the mechanism for improving the quality of agricultural products and the evolution of agro-ecological communities. 
Author Contributions: S.S. curated the relevant data and prepared the original draft. X.W. supplemented and edited the draft manuscript. T.N.V.K.V.P. reviewed and edited the draft manuscript. B.L. conceptualized, reviewed and edited the manuscript. All authors have read and agreed to the published version of the manuscript.

Funding: This work was supported by the National Natural Science Foundation of China (grant number 41772360, 41373078).

Acknowledgments: We are grateful to the editor for his language polish and we thank the anonymous reviewers for their insightful suggestions.

Conflicts of Interest: The authors declare that they have no conflict of interest.

\section{References}

1. Osman, K.T. Soil resources and soil degradation. In Soil Degradation, Conservation and Remediation; Springer: Berlin/Heidelberg, Germany, 2014; pp. 1-43.

2. Lin, W.W.; Lin, M.; Zhou, H.; Wu, H.; Li, Z.W.; Lin, W.X. The effects of chemical and organic fertilizer usage on rhizosphere soil in tea orchards. PLoS ONE 2019, 14, e0217018. [CrossRef] [PubMed]

3. Xiao, L.; Sun, Q.; Yuan, H.; Lian, B.A. Practical soil management to improve soil quality by applying mineral organic fertilizer. Acta Geochim. 2017, 36, 198-204. [CrossRef]

4. Xiao, L.; Sun, Q.; Yuan, H.; Li, X.; Chu, Y.; Ruan, Y.; Lian, B. A feasible way to increase carbon sequestration by adding dolomite and K-feldspar to soil. Cogent Geosci. 2016, 2, 1205324. [CrossRef]

5. Sun, Q.; Ruan, Y.; Chen, P.; Wang, S.; Liu, X.; Lian, B. Effects of mineral-organic fertilizer on the biomass of green Chinese cabbage and potential carbon sequestration ability in karst areas of Southwest China. Acta Geochim. 2019, 38, 430-439. [CrossRef]

6. Slessarev, E.W.; Chadwick, O.A.; Sokol, N.W.; Nuccio, E.E.; Pett-Ridge, J. Rock weathering controls the potential for soil carbon storage at a continental scale. Biogeochemistry. 2021. [CrossRef]

7. Wang, Q.; Wang, R.; He, L.; Sheng, X. Location-related differences in weathering behaviors and populations of culturable rock-weathering bacteria along a hillside of a rock mountain. Microb. Ecol. 2017, 73, 838-849. [CrossRef]

8. Yang, X.; Lian, B.; Zhu, X.L.; An, Y.L.; Chen, J.; Zhu, L.J. Effects of adding potassium-bearing mineral powder on nitrogen, potassium and potassium contents of chicken manure compost. Earth Environ. 2012, 40, $286-292$.

9. Ditta, A.; Muhammad, J.; Imtiaz, M.; Mehmood, S.; Qian, Z.; Tu, S. Application of rock phosphate enriched composts increases nodulation, growth and yield of chickpea. Int. J. Recycl. Org. Waste Agric. 2018, 7, 33-40. [CrossRef]

10. Niamat, B.; Naveed, M.; Ahmad, Z.; Yaseen, M.; Ditta, A.; Mustafa, A.; Xu, M. Calcium-enriched animal manure alleviates the adverse effects of salt stress on growth, physiology and nutrients homeostasis of Zea mays L. Plants 2019, 8, 480. [CrossRef]

11. Masruroh, A.; Minardi, S. Rock phosphate, zeolite and quail manure to enhance potassium uptake and yield of soybean on alfisols. Asian J. Soil Sci. Plant Nutr. 2019, 5, 1-9. [CrossRef]

12. Li, Y.; Liu, X.M.; Zhang, L.; Xie, Y.H.; Cai, X.L.; Wang, S.J.; Lian, B. Effects of short-term application of chemical and organic fertilizers on bacterial diversity of cornfield soil in a karst area. J. Soil Sci. Plant Nutr. 2020, 20, 2048-2058. [CrossRef]

13. Thorley, R.M.S.; Taylor, L.L.; Banwart, S.A.; Leake, J.R.; Beerling, D.J. The role of forest trees and their mycorrhizal fungi in carbonate rock wearthering and its significance for global carbon cycling. Plant Cell Environ. 2015, 38, 1947-1961. [CrossRef]

14. Zheng, X.; Zhu, Y.; Wang, Z.; Zhang, H.; Chen, M.; Chen, Y.; Liu, B. Effects of a novel bio-organic fertilizer on the composition of rhizobacterial communities and bacterial wilt outbreak in a continuously mono-cropped tomato field. Appl. Soil Ecol. 2020, 156, 103717. [CrossRef]

15. Han, Y.; Feng, G.; Swaney, D.P.; Dentener, F.; Koeble, R.; Ouyang, Y.; Gao, W. Global and regional estimation of net anthropogenic nitrogen inputs (NANI). Geoderma 2020, 361, 114066. [CrossRef]

16. Food and Agriculture Organization. Available online: http://fenix.fao.org/faostat/internal/en/\#data (accessed on 18 October 2021).

17. Chianu, J.N.; Mairura, F. Mineral fertilizers in the farming systems of sub-Saharan Africa-A review. Agron. Sustain. Dev. 2012, 32, 545-566. [CrossRef]

18. Geisseler, D.; Scow, K.M. Long-term effects of mineral fertilizers on soil microorganisms-A review. Soil Biol. Biochem. 2014, 75, 54-63. [CrossRef]

19. Lambrecht, I.; Vanlauwe, B.; Merckx, R.; Maertens, M. Understanding the process of agricultural technology adoption: Mineral fertilizer in eastern DR Congo. World Dev. 2014, 59, 132-146. [CrossRef]

20. Egodawatta, W.C.P.; Sangakkara, U.R.; Stamp, P. Impact of green manure and mineral fertilizer inputs on soil organic matter and crop productivity in a sloping landscape of Sri Lanka. Field Crop. Res. 2012, 129, 21-27. [CrossRef]

21. Du, N.X.T. Effects of green manures during fallow on moisture and nutrients of soil and winter wheat yield on the Loss Plateau of China. Emir. J. Food Agric. 2017, 29, 978-987.

22. Flores-Félix, J.D.; Menéndez, E.; Rivas, R.; de la Encarnación Velázquez, M. Future perspective in organic farming fertilization: Management and product. In Organic Farming; Woodhead Publishing: Sawston, UK, 2018; pp. 269-315.

23. Zhu, B.; Wang, T.; You, X.; Gao, M.R. Nutrient release from weathering of purplish rocks in the Sichuan Basin, China. Pedosphere 2008, 18, 257-264. [CrossRef] 
24. Bieluczyk, W.; Piccolo, M.; Pereira, M.G. Integrated farming systems influence soil organic matter dynamics in southeastern Brazil. Geoderma 2020, 371, 114368. [CrossRef]

25. Bronick, C.J.; Lal, R. Soil structure and management: A review. Geoderma 2005, 124, 3-22. [CrossRef]

26. Lian, B.; Chen, Y.; Zhu, L.; Yang, R. Effect of microbial weathering on carbonate rocks. Earth Sci. Front. 2008, 15, 90-99. [CrossRef]

27. Yang, Y.; Syed, S.; Mao, S.; Li, Q.; Ge, F.; Lian, B.; Lu, C.M. Bio-organic-mineral fertilizer can remediate chemical fertilizeroversupplied soil: Purslane planting as an example. J. Soil Sci. Plant Nutr. 2020, 20, 892-900. [CrossRef]

28. Li, M.; Li, Q.; Yun, J.; Yang, X.; Wang, X.; Lian, B.; Lu, C.M. Bio-organic-mineral fertilizer can improve soil quality and promote the growth and quality of water spinach. Can. J. Soil Sci. 2017, 97, 552-560. [CrossRef]

29. Li, R.Y.; Pang, Z.Q.; Zhou, Y.M.; Fyumah, N.; Hu, C.H.; Lin, W.X.; Yuan, Z.N. Metagenomic analysis exploring taxonomic and functional diversity of soil microbial communities in sugarcane fields applied with organic fertilizer. BioMed Res. Int. 2020, 2020, 9381506. [CrossRef]

30. Sindhu, S.S.; Parmar, P.; Phour, M.; Sehrawat, A. Potassium-solubilizing microorganisms (KSMs) and its effect on plant growth improvement. In Potassium Solubilizing Microorganisms for Sustainable Agriculture; Springer: Berlin/Heidelberg, Germany, 2016; pp. 171-185.

31. Etesami, H.; Emami, S.; Alikhani, H.A. Potassium solubilizing bacteria (KSB): Mechanisms, promotion of plant growth, and future prospects-A review. J. Soil Sci. Plant Nutr. 2017, 17, 897-911. [CrossRef]

32. Ribeiro, I.D.A.; Volpiano, C.G.; Vargas, L.K.; Granada, C.E.; Lisboa, B.B.; Passaglia, L.M.P. Use of mineral weathering bacteria to enhance nutrient availability in crops: A review. Front. Plant Sci. 2020, 11, 590774. [CrossRef]

33. Berde, C.V.; Gawde, S.S.; Berde, V.B. Potassium solubilization: Mechanism and functional impact on plant growth. In Soil Microbiomes for Sustainable Agriculture; Springer: Berlin/Heidelberg, Germany, 2021.

34. Goswami, D.; Parmar, S.; Vaghela, H.; Dhandhukia, P.; Thakker, J.N. Describing Paenibacillus mucilaginosus strain N3 as an efficient plant growth promoting rhizobacteria (PGPR). Cogent Food Agric. 2015, 1, 1000714. [CrossRef]

35. Wang, P.; Wu, S.H.; Wen, M.X.; Wang, Y.; Wu, Q.S. Effects of combined inoculation with rhizophagus intraradices and Paenibacillus mucilaginosus on plant growth, root morphology, and physiological status of trifoliate orange (Poncirus trifoliata L. Raf.) seedlings under different levels of phosphorus. Sci. Hortic. 2016, 205, 97-105. [CrossRef]

36. Chen, Y.H.; Yang, X.Z.; Li, Z.; An, X.H.; Ma, R.P.; Li, Y.Q.; Cheng, C.G. Efficiency of potassium-solubilizing paenibacillus mucilaginosus for the growth of apple seedling. J. Integr. Agric. 2020, 19, 2458-2469. [CrossRef]

37. Basak, B.B. Recycling of waste biomass and mineral powder for preparation of potassium-enriched compost. J. Mater. Cycles Waste Manag. 2018, 20, 1409-1415. [CrossRef]

38. Basak, B.B.; Maity, A.; Biswas, D.R. Cycling of natural sources of phosphorus and potassium for environmental sustainability. Biogeochemical Cycles: Ecological Drivers and Environmental Impact; Advancing Earth and Space Science: Washington, DC, USA, 2020; pp. 285-299.

39. Yu, X.D.; Wang, B.; Lian, B. Effect of organic fermentative fertilizer made from potassium-bearing rocks in the growth of amaranth mangostanus. Soil Fertil. Sci. China. 2011, 2, 61-64.

40. Chen, P.; Ruan, Y.L.; Wang, S.J.; Liu, X.M.; Lian, B. Effects of organic mineral fertiliser on heavy metal migration and potential carbon sink in soils in a karst region. Acta Geochim. 2017, 36, 539-543. [CrossRef]

41. Belov, S.V.; Danyleiko, Y.K.; Glinushkin, A.P.; Kalinitchenko, V.P.; Egorov, A.V.; Sidorov, V.A.; Izmailov, A.Y. An activated potassium phosphate fertilizer solution for stimulating the growth of agricultural plants. Front. Phys. 2021, 8, 618320. [CrossRef]

42. Zoca, S.M.; Penn, C. An important tool with no instruction manual: A review of gypsum use in agriculture. Adv. Agron. 2017, $144,1-44$.

43. Noordin, W.D.; Zulkefly, S.; Shamshuddin, J.; Hanafi, M.M. Improving soil chemical properties and growth performance of Hevea brasiliensis through basalt application. Int. Proc. IRC 2017, 2017, 308-323. [CrossRef]

44. Sheldrick, W.; Syers, J.K.; Lingard, J. Contribution of livestock excreta to nutrient balances. Nutr. Cycl. Agroecosyst. 2003, 66, 119-131. [CrossRef]

45. Manyuchi, M.M.; Phiri, A.; Muredzi, P.; Chitambwe, T. Comparison of vermicompost and vermiwash bio-fertilizers from vermicomposting waste corn pulp. Int. J. Biol. Biomol. Agric. Food Biotechnol. Eng. 2013, 7, 389-392.

46. Liu, H.T.; Chen, T.B.; Zhen, T.D.; Gao, D.; Lei, M. Comparative analysis of energy consumption, input cost and environmental benefit of organic fertilizer and chemical fertilizer production-take sludge composting to produce organic fertilizer as an example. Ecol. Environ. Sci. 2010, 19, 1000-1003.

47. Nacke, H.; Junior, G.; Schwantes, J.R.; Nava, L. Productivity and yield components of corn fertilized with different sources and levels of zinc. Span. J. Rural Dev. 2011, 2, 71-79. [CrossRef]

48. Vezzani, F.M.; Anderson, C.; Meenken, E.; Gillespie, R.; Peterson, M.; Beare, M.H. The importance of plants to development and maintenance of soil structure, microbial communities and ecosystem functions. Soil Tillage Res. 2018, 175, 139-149. [CrossRef]

49. Lazcano, C.; Gómez-Brandón, M.; Revilla, P.; Domínguez, J. Short-term effects of organic and inorganic fertilizers on soil microbial community structure and function. Biol. Fertil. Soils 2013, 49, 723-733. [CrossRef]

50. Huang, P.; Zhang, J.B.; Xin, X.L.; Zhu, A.N.; Zhang, C.Z.; Zhu, Q.G.; Wu, S.J. Proton accumulation accelerated by heavy chemical nitrogen fertilization and its long-term impact on acidifying rate in a typical arable soil in the Huang-Huai-Hai Plain. J. Integr. Agric. 2015, 14, 148-157. [CrossRef] 
51. Zamanian, K.; Zarebanadkouki, M.; Kuzyakov, Y. Nitrogen fertilization raises $\mathrm{CO}_{2}$ efflux from inorganic carbon: A global assessment. Glob. Chang. Biol. 2018, 24, 2810-2817. [CrossRef]

52. Raza, S.; Miao, N.; Wang, P.; Ju, X.; Chen, Z.; Zhou, J.; Kuzyakov, Y. Dramatic loss of inorganic carbon by nitrogen-induced soil acidification in Chinese croplands. Glob. Chang. Biol. 2020, 26, 3738-3751. [CrossRef]

53. Datta, S.P.; Rattan, R.K.; Chandra, S. Labile soil organic carbon, soil fertility, and crop productivity as influenced by manure and mineral fertilizers in the tropics. J. Plant Nutr. Soil Sci. 2010, 173, 715-726. [CrossRef]

54. Shen, Z.; Ruan, Y.; Chao, X.; Zhang, J.; Li, R.; Shen, Q. Rhizosphere microbial community manipulated by 2 years of consecutive biofertilizer application associated with banana fusarium wilt disease suppression. Biol. Fertil. Soils 2015, 51, 553-562. [CrossRef]

55. Verma, R.; Maurya, B.R.; Meena, V.S.; Dotaniya, M.L.; Deewan, P. Microbial dynamics as influenced by bio-organics and mineral fertilizer in alluvium soil of Varanasi, India. Int. J. Curr. Microbiol. Appl. Sci. 2017, 6, 1516-1524. [CrossRef]

56. Verma, R.; Maurya, B.R.; Meena, V.S.; Dotaniya, M.L.; Deewan, P.; Jajoria, M. Enhancing production potential of cabbage and improves soil fertility status of Indo-Gangetic Plain through application of bio-organics and mineral fertilizer. Int. J. Curr. Microbiol. Appl. Sci. 2017, 6, 301-309.

57. Mahajan, S.; Kanwar, S.S.; Sharma, S.P. Long-term effect of mineral fertilizers and amendments on microbial dynamics in an alfisol of Western Himalayas. Indian J. Microbiol. 2007, 47, 86-89. [CrossRef]

58. Diacono, M.; Montemurro, F. Long-term effects of organic amendments on soil fertility-A review. Agron. Sustain. Dev. 2010, 30, 401-422. [CrossRef]

59. Huang, N.; Wang, W.W.; Yao, Y.L.; Zhu, F.X.; Wang, W.P.; Chang, X.J. The influence of different concentrations of bio-organic fertilizer on cucumber fusarium wilt and soil microflora alterations. PLoS ONE 2017, 12, e0171490. [CrossRef]

60. Yang, W.H.; Chang, J.; Wang, S.S.; Zhou, B.Q.; Mao, Y.L.; Rensing, C.; Xing, S.H. Influence of biochar and biochar-based fertilizer on yield, quality of tea and microbial community in an acid tea orchard soil. Appl. Soil Ecol. 2021, 166, 104005. [CrossRef] 